
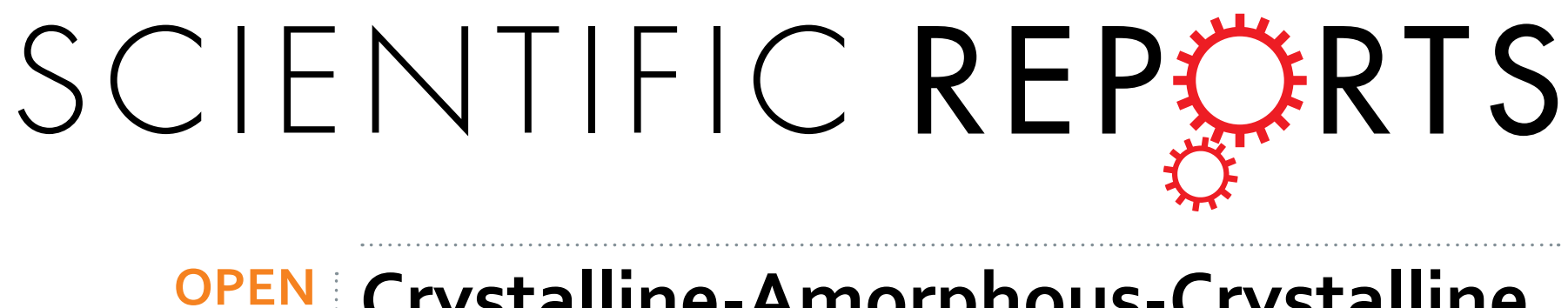

Received: 11 January 2016

Accepted: 25 April 2016

Published: 17 May 2016

\title{
Crystalline-Amorphous-Crystalline Transformation in a Highly Brilliant Luminescent System with Trigonal- Planar Gold(I) Centers
}

Kosuke Igawa ${ }^{1}$, Nobuto Yoshinari ${ }^{1}$, Mitsutaka Okumura ${ }^{1}$, Hiroyoshi Ohtsu ${ }^{2}$, Masaki Kawano ${ }^{2,3}$ \& Takumi Konno ${ }^{1}$

Photoluminescent compounds showing emission color changes in response to external stimuli have received considerable attention because of their wide range of applications. Here, we report the unique photoluminescence behavior of a digold $(\mathrm{I})$ coordination system with trigonal-planar $\mathrm{Au}^{\prime}$ centers, $\left[\mathrm{Au}_{2}(\mathrm{dppm})_{3}\right]^{2+}(\mathrm{dppm}=$ bis(diphenylphosphino)methane). This system shows an extremely intense phosphorescence, with a quantum yield of $>95 \%$ in the solid state. Both the emission color and thermal stability vary due to changing counter ions $\left(\mathrm{Cl}^{-}\right.$vs. OTf $\left.{ }^{-}\right)$. Of particular note is the thermal crystalline-amorphous-crystalline transformation for the chloride salt, which is accompanied by drastic emission color changes. Single-crystal and powder X-ray diffractions demonstrate that the two-step transformation is induced by the loss of water molecules of crystallization with the subsequent removal of a dppm ligand to form $\left[\mathrm{Au}_{2}(\mathrm{dppm})_{2}\right]^{2+}$, which is mechanically reverted back to $\left[\mathrm{Au}_{2}(\mathrm{dppm})_{3}\right]^{2+}$.

Chromic luminescent compounds whose emission energies and intensities change in response to external stimuli have received increasing attention because of their potential applications as chemical/biological probes and organic light-emitting diodes ${ }^{1-3}$. These compounds often involve $\mathrm{Au}^{\mathrm{I}}$ ions as a metal component ${ }^{4-9}$, in which their photo-luminescence is highly sensitive to the change in intramolecular and intermolecular $\mathrm{Au}$-..Au aurophilic interactions $^{10,11}$. Thus far, organic vapors ${ }^{4}$, solvents ${ }^{5}$, counter anions ${ }^{6}$, metal ions ${ }^{7}$, temperature ${ }^{8}$, and mechanical force ${ }^{9}$ have been used as triggers to change the emission colors and intensities of gold(I) compounds. Generally, each $\mathrm{Au}^{\mathrm{I}}$ center of these compounds has a two-coordinated linear geometry ${ }^{12,13}$. This geometry enables them to form an effective $\mathrm{Au} \cdots \mathrm{Au}$ interaction and to accept another donor that exists as a counter ion or solvent molecule to their vacant coordination sites. In contrast, the chromic behavior has not been reported for those containing three-coordinated, trigonal-planar $\mathrm{Au}^{\mathrm{I}}$ centers $^{14-16}$. This is surprising because three-coordinated gold(I) species are expected to show a stronger photo-luminescence due to the steric crowdedness around each $\mathrm{Au}^{\mathrm{I}}$ center, which can inhibit non-radiative processes ${ }^{17}$. In this context, we started to investigate the photo-luminescent properties of a typical digold(I) complex, $\left[\mathrm{Au}_{2}(\mathrm{dppm})_{3}\right]^{2+}\left(\mathrm{dppm}=\right.$ bis(diphenylphosphino)metane, $\left.[1]^{2+}\right)$, in which two $\mathrm{Au}^{\mathrm{I}}$ centers are triply bridged by three dppm ligands. This complex was prepared and isolated as bromide and perchlorate salts by McAuliffe and coworkers in 1985, who proposed that each $\mathrm{Au}^{\mathrm{I}}$ center in $[1]^{2+}$ has a trigonal-planar geometry based on the ${ }^{31} \mathrm{P} \mathrm{NMR}$ spectroscopic and elemental analytical results ${ }^{18}$. However, its crystal structure and emission property have not yet been investigated. In this study, we succeeded in the crystallization and structural characterization of the chloride and trifluoromethanesulfonate $\left(\mathrm{OTf}^{-}\right)$salts of $[1]^{2+}$. In the solid state, both salts exhibit a quite brilliant emission, green for the chloride salt and yellow-green for the $\mathrm{OTf}^{-}$salt, with a quantum yield of $>95 \%$. More remarkably, a reversible, two-step emission color change from green to blue via yellow, induced by the loss of water molecules of crystallization with the subsequent loss of one of three bridging dppm ligands to form $\left[\mathrm{Au}_{2}(\mathrm{dppm})_{2}\right]^{2+}\left([2]^{2+}\right)$, was detected for the chloride salt in the solid state (Fig. 1). To our knowledge, such a fascinating chromic luminescence has never been reported for gold(I) compounds with trigonal-planer $\mathrm{Au}^{\mathrm{I}}$ centers.

${ }^{1}$ Department of Chemistry, Graduate School of Science, Osaka University, Toyonaka, Osaka 560-0043, Japan. ${ }^{2}$ The Division of Advanced Materials Science, Pohang University of Science and Technology (POSTECH), San 31, Hyojadong, Pohang 790-784, Korea. ${ }^{3}$ Department of Chemistry, Graduate School of Science and Engineering, Tokyo Institute of Technology, 2-12-1 Ookayama, Meguro-ku, Tokyo 152-8550, Japan. Correspondence and requests for materials should be addressed toT.K. (email: konno@chem.sci.osaka-u.ac.jp) 


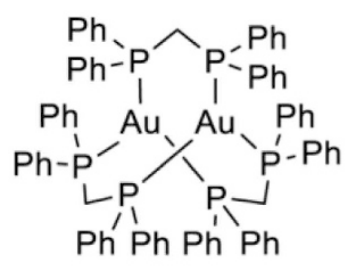

$[1] \mathrm{Cl}_{2} 8.5 \mathrm{H}_{2} \mathrm{O}$

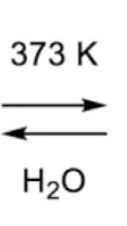<smiles>c1ccc(P(CP(CP(c2ccccc2)c2ccccc2)(c2ccccc2)(c2ccccc2)P(c2ccccc2)(c2ccccc2)(c2ccccc2)P(c2ccccc2)c2ccccc2)c2ccccc2)cc1</smiles>

$[1] \mathrm{Cl}_{2}$

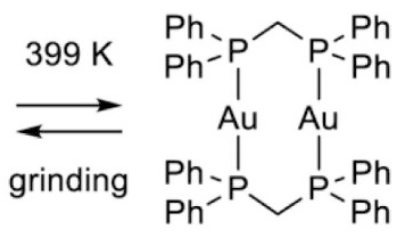

$[2] \mathrm{Cl}_{2}+\mathrm{dppm}$

Figure 1. Reversible two-step conversion of $[1] \mathrm{Cl}_{2} \cdot 8.5 \mathrm{H}_{2} \mathrm{O}$.

a

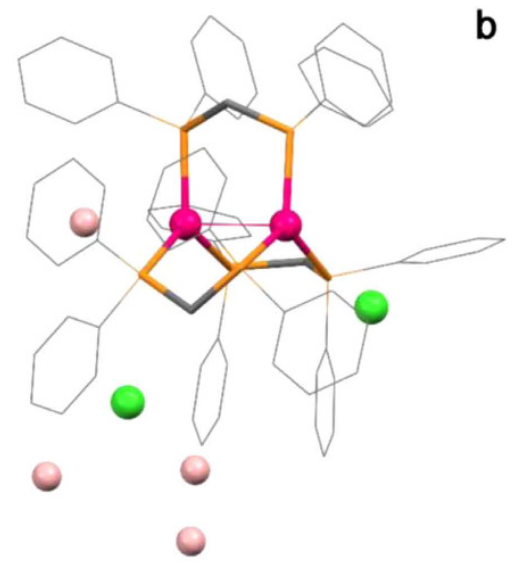

b

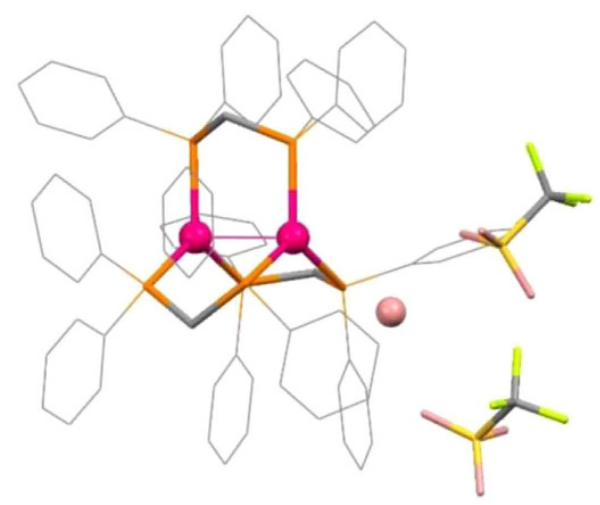

C

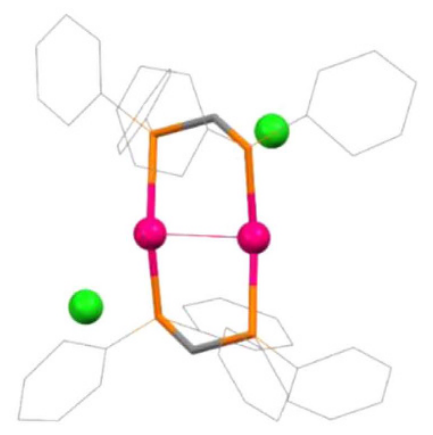

Figure 2. Crystal structures of $[1]^{2+}$ and $[2]^{2+}$. Perspective views of $(\mathbf{a}),[1] \mathrm{Cl}_{2} \cdot 8.5 \mathrm{H}_{2} \mathrm{O},(\mathbf{b})[1](\mathrm{OTf})_{2} \cdot \mathrm{H}_{2} \mathrm{O}$ and (c) $[2] \mathrm{Cl}_{2}$. Color Codes: $\mathrm{Au}$, red; $\mathrm{P}$, orange; $\mathrm{S}$, yellow; $\mathrm{Cl}$, green; $\mathrm{C}$, gray; $\mathrm{O}$, pink; F, light green.

\section{Results}

Synthesis and structural characterization of $[1] \mathrm{Cl}_{2} \cdot 8.5 \mathrm{H}_{2} \mathrm{O}$ and $[1](\mathrm{OTf})_{2} \cdot \mathrm{H}_{2} \mathrm{O}$. Treatment of $\left[\mathrm{Au}_{2} \mathrm{Cl}_{2}(\mathrm{dppm})\right]^{19}$ with dppm at a $1: 2$ ratio in $\mathrm{MeOH} / \mathrm{H}_{2} \mathrm{O}$ produced a clear yellow solution, from which the chloride salt of $[1]^{2+}\left([1] \mathrm{Cl}_{2} \cdot 8.5 \mathrm{H}_{2} \mathrm{O}\right)$ was isolated as pale yellow block crystals at a high yield. The OTf ${ }^{-}$salt of $[1]^{2+}\left([1](\mathrm{OTf})_{2} \cdot \mathrm{H}_{2} \mathrm{O}\right)$ was also obtained as pale yellow platelet crystals by adding NaOTf to the yellow reaction solution. The elemental and thermogravimetric (TG) analytical data implied that freshly prepared crystals of the chloride and OTf $^{-}$salts contained 8.5 water molecules and one water molecule per one complex cation, respectively. The presence of water molecules in each compound was confirmed by IR spectroscopy, showing a broad band at approximately $3400 \mathrm{~cm}^{-1}$ (Supplementary Fig. 1$)^{20}$.

Single-crystal X-ray crystallography indicated that $[1] \mathrm{Cl}_{2} \cdot 8.5 \mathrm{H}_{2} \mathrm{O}$ is crystallized in a cubic space group $\mathrm{Pa}-3$, consisting of one third of the complex cation of $[1]^{2+}$, two thirds of chloride anions, and two and five sixths of water molecules of crystallization in the asymmetric unit. The entire complex cation contains two $\mathrm{Au}^{\mathrm{I}}$ ions that are triply bridged by three dppm ligands, forming a digold(I) structure in $\left[\mathrm{Au}_{2}(\mathrm{dppm})_{3}\right]^{2+}$ (Fig. 2a). Each $\mathrm{Au}^{\mathrm{I}}$ ion, which lies on a crystallographic $C_{3}$ axis, is coordinated by three $\mathrm{P}$ atoms from three different dppm ligands in an ideal trigonal-planar geometry (av. $\mathrm{Au}-\mathrm{P}=2.41 \AA$ and $\mathrm{P}-\mathrm{Au}-\mathrm{P}=120^{\circ}$ ). This triply bridged structure in $[1]^{2+}$ is reminiscent of that found in the corresponding disilver(I) complex, $\left[\mathrm{Ag}_{2}(\mathrm{dppm})_{3}\right]^{2+21}$. The intramolecular separation between two $\mathrm{Au}^{\mathrm{I}}$ centers in $[1] \mathrm{Cl}_{2} \cdot 8.5 \mathrm{H}_{2} \mathrm{O}$ is $3.03 \AA$, suggestive of the presence of an aurophilic interaction. In crystal, there exist intermolecular $\mathrm{CH} \cdots \pi$ interactions between complex cations $(\mathrm{C} \cdots \mathrm{Ph}=3.07-3.50 \AA \AA)$. 
a

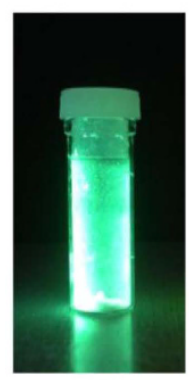

b

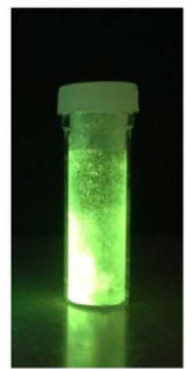

C

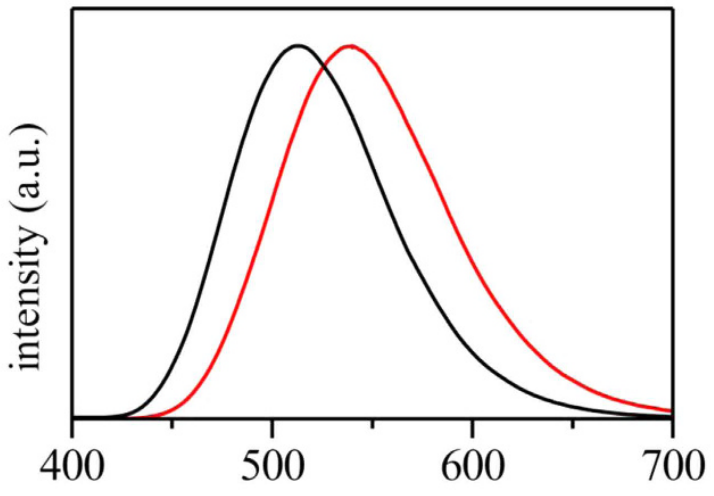

wavelength / nm

Figure 3. Phosphorescence of $[1] \mathrm{Cl}_{2}$ and $[1](\mathrm{OTf})_{2}$. Photographs of $(\mathbf{a}),[1] \mathrm{Cl}_{2} \cdot 8 \cdot 5 \mathrm{H}_{2} \mathrm{O}$, and $(\mathbf{b})[1]$ $(\mathrm{OTf})_{2} \cdot \mathrm{H}_{2} \mathrm{O}$ under UV light. (c) Emission spectra of $[1] \mathrm{Cl}_{2}$ (black) and [1](OTf $)_{2}$ (red) in the solid state at room temperature. $\left(\lambda_{\mathrm{ex}}=390 \mathrm{~nm}\right)$

Moreover, two $\mathrm{Cl}^{-}$counter anions and water molecules of crystallization are located around each complex cation, forming $\mathrm{CH} \cdots \mathrm{Cl}(\mathrm{C} \cdots \mathrm{Cl}=3.56-3.81 \AA)$ and $\mathrm{OH} \cdots \mathrm{Cl}(\mathrm{O} \cdots \mathrm{Cl}=2.91-2.96 \AA)$ interactions.

Single-crystal X-ray analysis indicated that [1] $(\mathrm{OTf})_{2} \cdot \mathrm{H}_{2} \mathrm{O}$ is crystallized in a monoclinic space group $P 2_{1} / n$, consisting of two complex cations of $[1]^{2+}\left(\mathrm{av} . \mathrm{Au}-\mathrm{P}=2.39 \mathrm{~A}\right.$ and av. $\left.\mathrm{P}-\mathrm{Au}-\mathrm{P}=120^{\circ}\right)$, four $\mathrm{OTf}^{-}$anions, and two water molecules of crystallization in the asymmetric unit. The digold(I) structure of each complex cation in this compound is nearly the same as that found in $[1] \mathrm{Cl}_{2} \cdot 8 \cdot 5 \mathrm{H}_{2} \mathrm{O}$ (Fig. 2b). The intramolecular separations between two $\mathrm{Au}^{\mathrm{I}}$ centers in the two complex cations are 2.97 and $2.99 \AA$, which are slightly shorter than the separation in $[1] \mathrm{Cl}_{2} \cdot 8.5 \mathrm{H}_{2} \mathrm{O}(3.03 \AA)$. The relatively strong $\mathrm{CH} \cdots \mathrm{O} / \mathrm{F}(\mathrm{C} \cdots \mathrm{O}=3.06-3.30 \AA, \mathrm{C} \cdots \mathrm{F}=3.18-3.58 \AA)$ interactions between a complex cation and $\mathrm{OTf}^{-}$anion, as well as intermolecular $\mathrm{CH} \cdots \pi$ interactions between complex cations $(\mathrm{C} \cdots \mathrm{Ph}=3.17-3.61 \AA)$, are found in $[1](\mathrm{OTf})_{2} \cdot \mathrm{H}_{2} \mathrm{O}$.

Photoluminescence behavior of $[1] \mathrm{Cl}_{2} \cdot 8.5 \mathrm{H}_{2} \mathrm{O}$ and $[1](\mathrm{OTf})_{2} \cdot \mathrm{H}_{2} \mathrm{O}$. Under UV light irradiation at room temperature, solid samples of $[1] \mathrm{Cl}_{2} \cdot 8 \cdot 5 \mathrm{H}_{2} \mathrm{O}$ and $[1](\mathrm{OTf})_{2} \cdot \mathrm{H}_{2} \mathrm{O}$ showed strong green and yellow-green emissions, respectively (Fig. 3a,b). In the emission spectra, [1] $\mathrm{Cl}_{2} \cdot 8.5 \mathrm{H}_{2} \mathrm{O}$ and [1](OTf $)_{2} \cdot \mathrm{H}_{2} \mathrm{O}$ showed broad bands centered at 413 and $440 \mathrm{~nm}$, respectively. The emission lifetimes for [1] $\mathrm{Cl}_{2} \cdot 8.5 \mathrm{H}_{2} \mathrm{O}$ and [1] $(\mathrm{OTf})_{2} \cdot \mathrm{H}_{2} \mathrm{O}$ were estimated to be $4.51 \mu \mathrm{s}$ and $4.15 \mu \mathrm{s}$, respectively (Supplementary Fig. 2), indicative of the phosphorescent character of emission for both compounds. Time-dependent density functional theory (TD-DFT) calculations of [1] $\mathrm{Cl}_{2} \cdot \mathrm{H}_{2} \mathrm{O}$ showed intense absorption at 325.6 and $324.8 \mathrm{~nm}$, which involved one-electron transitions from HOMO-11 to LUMO and HOMO-12 to LUMO, respectively. These MOs possessed a large contribution from the $\mathrm{Au} \cdots \mathrm{Au}$ core (Supplementary Figs 3 and 4). Moreover, the DFT calculations confirmed that the luminescence of this compound has a phosphorescent character due to an intersystem crossing from the lowest singlet excited $\left(\mathrm{S}_{1}\right)$ state to the lowest triplet excited $(\mathrm{T})$ state; the calculated emission wavelength $(511 \mathrm{~nm})$ of the luminescence was highly similar to the experimental one. Notably, the internal luminescence quantum yields $(\Phi)$ for both salts were estimated to be more than $95 \%$ based on the absolute method using an integrating sphere. This value is considerably greater than that for the corresponding doubly bridged digold(I) complex, $\left[\mathrm{Au}_{2} \mathrm{Cl}_{2}(\mathrm{dppm})_{2}\right]^{12}$; the quantum yield of this complex was estimated to be $69 \%\left(\lambda_{\mathrm{em}}=480 \mathrm{~nm}\right)$ under the same conditions. The emission band of $[1] \mathrm{Cl}_{2} \cdot 8.5 \mathrm{H}_{2} \mathrm{O}$ and $[1](\mathrm{OTf})_{2} \cdot \mathrm{H}_{2} \mathrm{O}$ shifted slightly (by $10-15 \mathrm{~nm}$ ) to longer wavelength when the temperature was lowered to $77 \mathrm{~K}$, indicative of a stronger $\mathrm{Au} \cdots \mathrm{Au}$ interaction in the excitation state at lower temperature (Supplementary Fig. 5). In addition, the emission lifetime (ca. $5 \mu \mathrm{s}$ ) observed at $77 \mathrm{~K}$ was nearly the same as that (ca. $4 \mu \mathrm{s}$ ) observed at room temperature (Supplementary Fig. 2), and the quantum yields of [1] $\mathrm{Cl}_{2} \cdot 8 \cdot 5 \mathrm{H}_{2} \mathrm{O}$ and [1] $(\mathrm{OTf})_{2} \cdot \mathrm{H}_{2} \mathrm{O}$ were still very high at $77 \mathrm{~K}$. [1] $\mathrm{Cl}_{2} \cdot 8.5 \mathrm{H}_{2} \mathrm{O}$ and $[1](\mathrm{OTf})_{2} \cdot \mathrm{H}_{2} \mathrm{O}$ dissolved in methanol showed a weak yellow emission ( $\lambda_{\mathrm{em}}=592 \mathrm{~nm}, \Phi<1 \%$, Supplementary Fig. 6), presumably because of the equilibrium between the triply bridged structure in $[1]^{2+}$ and the doubly bridged structure in $\left[\mathrm{Au}_{2}(\mathrm{dppm})_{2}\right]^{2+}\left([2]^{2+}\right)$ in the solution ${ }^{22}$.

Two-step thermal transformation with emission color change. The TG analysis of $[1] \mathrm{Cl}_{2} \cdot 8 \cdot 5 \mathrm{H}_{2} \mathrm{O}$ indicated that a gradual weight loss of $8.0 \%$, which corresponds to the loss of 8.5 water molecules, occurred until $373 \mathrm{~K}$ to give a dehydrated form, followed by its decomposition at $573 \mathrm{~K}$ (Supplementary Fig. 7). Although no weight loss was observed between 373 and $473 \mathrm{~K}$, the differential scanning calorimetry (DSC) showed an exothermal peak at $399 \mathrm{~K}$, indicative of the occurrence of an endothermal reaction at this temperature. In parallel with the dehydration reaction and subsequent endothermal reactions, dramatic changes in the original emission color were recognized; the emission color changed from green to yellow when a solid sample of $[1] \mathrm{Cl}_{2} \cdot 8.5 \mathrm{H}_{2} \mathrm{O}$ was heated at $373 \mathrm{~K}$, and further heating to $399 \mathrm{~K}$ caused the color change to blue (Fig. 4a). In the emission spectra, the sample heated at $373 \mathrm{~K}$ showed an emission band at $596 \mathrm{~nm}$ with a quantum yield of $52 \%$, whereas the sample heated at $399 \mathrm{~K}$ showed an emission band at $470 \mathrm{~nm}$ with a quantum yield of $55 \%$ (Fig. $4 \mathrm{~b}$ ). 
a

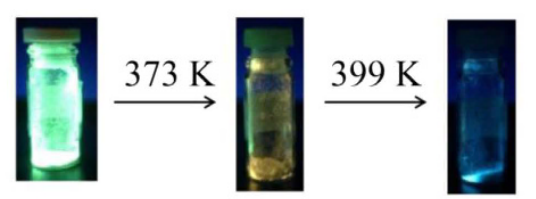

b

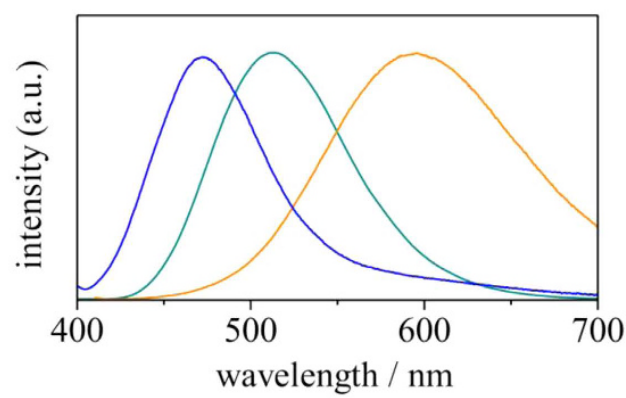

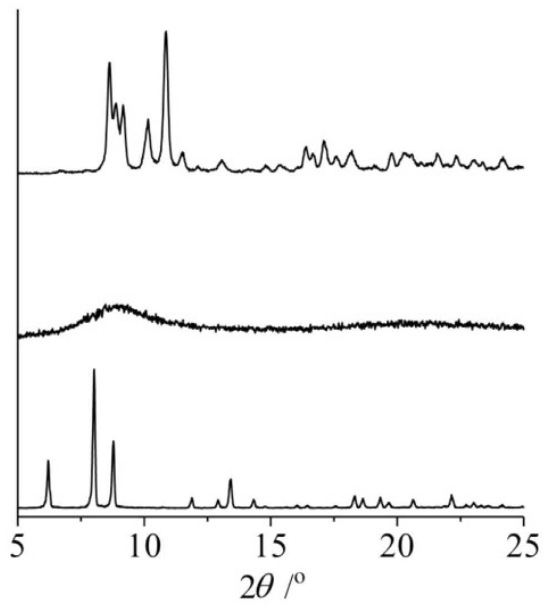

Figure 4. Emission color changes of $[1] \mathrm{Cl}_{2} \cdot 8.5 \mathrm{H}_{2} \mathrm{O}$ by heating. (a) Photographs under UV light and (b) emission spectra of fresh (green line) and heated samples (treated at $373 \mathrm{~K}$, yellow line; at $399 \mathrm{~K}$, blue line) of $[1] \mathrm{Cl}_{2} \cdot 8.5 \mathrm{H}_{2} \mathrm{O}$.

We carried out a solid-state ${ }^{31} \mathrm{P}$ NMR spectroscopy and powder X-ray diffraction (PXRD) study to characterize the two species formed by heating at 373 and $399 \mathrm{~K}$. The ${ }^{31} \mathrm{P}$ NMR spectrum of an original solid sample of [1] $\mathrm{Cl}_{2} \cdot 8.5 \mathrm{H}_{2} \mathrm{O}$ showed a signal centered at $\delta 18 \mathrm{ppm}$ (Supplementary Fig. 8), which was assigned to P donors bound to $\mathrm{Au}^{\mathrm{I}}$ centers. The same NMR spectral feature was observed for the sample heated at $373 \mathrm{~K}$, indicative of the retention of the digold(I) structure in $[1]^{2+}$ by dehydration. In contrast, the sample heated at $399 \mathrm{~K}$ exhibited a new signal at $\delta-44 \mathrm{ppm}$. Because the signal at $\delta-44 \mathrm{ppm}$ corresponds well with that observed for a solid sample of dppm, the heating of $[1] \mathrm{Cl}_{2}$ at $399 \mathrm{~K}$ causes the dissociation of a part of dppm ligands in $[1]^{2+}$. In the PXRD, the diffraction pattern of a solid sample of $[1] \mathrm{Cl}_{2} \cdot 8.5 \mathrm{H}_{2} \mathrm{O}$ was consistent with that simulated from its single-crystal $\mathrm{X}$-ray data. In contrast, no notable diffractions were observed for a sample heated at $373 \mathrm{~K}$. This is indicative of the collapse of the non-covalent intermolecular interactions due to the removal of water molecules of crystallization, thus converting them to an amorphous solid. Remarkably, the PXRD for a sample heated until $399 \mathrm{~K}$ exhibited sharp diffractions that were distinct from those for $[1] \mathrm{Cl}_{2} \cdot 8.5 \mathrm{H}_{2} \mathrm{O}$. The structure of this new crystalline phase was successfully determined by the high-resolution powder $\mathrm{X}$-ray diffraction using synchrotron radiation $(\lambda=1.30 \AA)$ (Fig. 2c, Supplementary Fig. 9), which revealed the presence of a complex cation of $[2]^{2+}$ and two chloride ions in the asymmetric unit. This complex cation contains two linear $\mathrm{Au}^{\mathrm{I}}$ ions that are bridged by two dppm ligands, and each $\mathrm{Au}^{\mathrm{I}}$ center has a diagonal $\mathrm{P}-\mathrm{Au}-\mathrm{I}$ geometry $\left(\mathrm{av}\right.$. $\mathrm{Au}-\mathrm{P}=2.34 \AA$ and $\mathrm{P}-\mathrm{Au}-\mathrm{P}=159^{\circ}$ ), with an $\mathrm{Au} \cdots \mathrm{Au}$ separation of $2.97 \AA$. In this structure, $\mathrm{Cl}^{-}$ions are not involved in the coordination $(\mathrm{Au} \cdots \mathrm{Cl}>3.6 \AA)$ but act as a counter anion with the formation of $\mathrm{CH}$... Cl interactions with neighboring complex cations. This structure is in sharp contrast to the previously reported structure in $\left[\mathrm{Au}_{2}(\mathrm{dppm})_{2} \mathrm{Cl}_{2}\right] \cdot$ acetone ${ }^{23}$, in which each $\mathrm{Cl}^{-}$ion weakly coordinates to an $\mathrm{Au}^{\mathrm{I}}$ center ( $\mathrm{av}$. $\mathrm{Au}-\mathrm{Cl}=2.77 \AA$ ) to form a $T$-shaped coordination geometry (Supplementary Fig. 10). Moreover, complex cations are connected to each other through multiple $\mathrm{CH} \cdots \pi$ or $\pi \cdots \pi$ interactions, forming a closely packed lattice structure. Whereas non-coordinating dppm molecules are not accommodated in this crystal lattice, the elemental analytical data and the solid-state ${ }^{31} \mathrm{P}$ NMR spectrum implied that the dppm molecules were not sublimated to air but were still contaminated as an amorphous solid in the sample heated at $399 \mathrm{~K}$.

When a blue-emissive crystalline powder of $[2] \mathrm{Cl}_{2}$ was manually ground in an agate mortar, a yellow-emissive amorphous powder of $[1] \mathrm{Cl}_{2}$ was produced. Moreover, the continuous grinding of the powder of $[1] \mathrm{Cl}_{2}$ after adding water produced a green-emissive crystalline powder of $[1] \mathrm{Cl}_{2} \cdot 8.5 \mathrm{H}_{2} \mathrm{O}$. The assignment of these powders was made using their emission spectra and PXRD profiles (Supplementary Figs 11 and 12), thus indicating the reverse conversion from $[2] \mathrm{Cl}_{2}$ to $[1] \mathrm{Cl}_{2}$ and then to $[1] \mathrm{Cl}_{2} \cdot 8.5 \mathrm{H}_{2} \mathrm{O}$. Here, no significant change in the emission color was observed for [1] $(\mathrm{OTf})_{2} \cdot \mathrm{H}_{2} \mathrm{O}$, even when its sample was heated to $473 \mathrm{~K}$. Furthermore, the emission spectrum and PXRD pattern of a sample heated at $473 \mathrm{~K}$ were essentially identical to those of the original sample (Supplementary Figs 13 and 14), illustrating that its thermal stability is considerably higher than that of the OTf $^{-}$salt of $[1]^{2+}$.

\section{Discussion}

We succeeded in the crystallization and structural characterization of $[1] \mathrm{Cl}_{2} \cdot 8.5 \mathrm{H}_{2} \mathrm{O}$ and $[1](\mathrm{OTf})_{2} \cdot \mathrm{H}_{2} \mathrm{O}$, in which two trigonal-planar $\mathrm{Au}^{\mathrm{I}}$ centers are triply bridged by dppm ligands. Solids $[1] \mathrm{Cl}_{2} \cdot 8.5 \mathrm{H}_{2} \mathrm{O}$ and $[1](\mathrm{OTf})_{2} \cdot \mathrm{H}_{2} \mathrm{O}$ exhibited brilliant green and yellow-green emissions, which were attributed to phosphorescence. The difference in the emission wavelengths between $[1] \mathrm{Cl}_{2} \cdot 8.5 \mathrm{H}_{2} \mathrm{O}$ and $[1](\mathrm{OTf})_{2} \cdot \mathrm{H}_{2} \mathrm{O}(\mathrm{ca} .30 \mathrm{~nm})$ was likely due to the slight but appreciable difference in their $\mathrm{Au} \cdots$ Au distances $\left(3.03 \AA\right.$ for $[1] \mathrm{Cl}_{2} \cdot 8.5 \mathrm{H}_{2} \mathrm{O}$ vs. $2.98 \AA$ for $\left.[1](\mathrm{OTf})_{2} \cdot \mathrm{H}_{2} \mathrm{O}\right)$. Remarkably, the phosphorescence for both [1] $\mathrm{Cl}_{2} \cdot 8 \cdot 5 \mathrm{H}_{2} \mathrm{O}$ and $[1](\mathrm{OTf})_{2} \cdot \mathrm{H}_{2} \mathrm{O}$ was found to have an excellent quantum yield of more than $95 \%$. This high quantum yield appears to be due to the molecular rigidity around two $\mathrm{Au}^{\mathrm{I}}$ ions tightly bridged by three dppm ligands, together with the multiple intermolecular interactions in crystal, which completely prevented a nonradiative deactivation. The molecular rigidity was supported by the DFT calculations, which revealed a quite small structural difference between the ground singlet $\left(\mathrm{S}_{0}\right)$ and triplet excited $(\mathrm{T})$ 
states in the optimized molecular structure in [1] $\mathrm{Cl}_{2}$ (Supplementary Fig. 15). More remarkably, [1] $\mathrm{Cl}_{2} \cdot 8.5 \mathrm{H}_{2} \mathrm{O}$ showed a two-step thermal transformation from its green-emissive crystalline phase to the blue-emissive crystalline phase $\left([2] \mathrm{Cl}_{2}\right)$ via the yellow-emissive amorphous phase $\left([1] \mathrm{Cl}_{2}\right)$, which was induced by the loss of water molecules of crystallization and the subsequent dissociation of a dppm ligand. The reverse conversion from [2] $\mathrm{Cl}_{2}$ to $[1] \mathrm{Cl}_{2} \cdot 8.5 \mathrm{H}_{2} \mathrm{O}$ by mechanical grinding in the presence of water via $[1] \mathrm{Cl}_{2}$ was also recognized. To our knowledge, this is the first phosphorescent system with a high quantum yield of $>95 \%$ that illustrates a reversible, crystalline-amorphous-crystalline thermal transformation accompanied by drastic emission color changes. Such a thermal transformation was not observed for $[1](\mathrm{OTf})_{2} \cdot \mathrm{H}_{2} \mathrm{O}$, which possesses a rigid crystalline framework, sustained by multiple cation-cation and cation-anion interactions without the mediation of water molecules. Thus, it is reasonable to consider that the water-molecule-mediated crystal structure in $[1] \mathrm{Cl}_{2} \cdot 8.5 \mathrm{H}_{2} \mathrm{O}$, which was converted to the loosely packed amorphous structure in $[1] \mathrm{Cl}_{2}$ via the removal of water molecules, together with the formation of the closely packed, non-hydrated crystal structure in $[2] \mathrm{Cl}_{2}$ via the removal of a dppm ligand, is responsible for this unique thermal transformation. Finally, the present study demonstrated that trigonal-planar $\mathrm{Au}^{\mathrm{I}}$ species are highly available for the future design and creation of functional luminescent materials.

\section{Methods}

Materials and equipment. All reagents and solvents used in synthetic studies were commercially available and used as supplied without further purification.

The IR spectra were recorded on a JASCO FT/IR-4100 infrared spectrophotometer using KBr disks at room temperature. The elemental analysis $(\mathrm{C}, \mathrm{H})$ was performed at Osaka University using YANACO CHN coda MT-5 or MT-6. The ${ }^{1} \mathrm{H}$ and ${ }^{31} \mathrm{P}$ NMR spectra in solution were measured using a JEOL EX-500 spectrometer at the probe temperature, using tetramethylsilane (TMS, $\delta 0.0 \mathrm{ppm}$ ) as the internal standard for ${ }^{1} \mathrm{H}$ NMR measurements and triphenyl phosphate $(\delta-17.6 \mathrm{ppm})$ as the external standard for ${ }^{31} \mathrm{P}$ NMR measurements. The ${ }^{1} \mathrm{H}$ and ${ }^{31} \mathrm{P}$ NMR spectra are illustrated in Supplementary Figs 16 and 17, respectively. The magic angle spinning (MAS) ${ }^{31} \mathrm{P}$ NMR spectra in the solid state were measured using a Chemagnetics CMX300 spectrometer at the probe temperature and spun at $7 \mathrm{kHz}$ for $[1] \mathrm{Cl}_{2} \cdot 8.5 \mathrm{H}_{2} \mathrm{O}$ and at $6 \mathrm{kHz}$ for $[1] \mathrm{Cl}_{2}$ and $[2] \mathrm{Cl}_{2}$, using triphenyl phosphate as the external standard. The TG and DTA measurements were measured using a SHIMADZU DTG-60 analyzer. The PXRD patterns were recorded using a BRUKER D2 PHASER at room temperature. High-quality PXRD patterns for structural determination were recorded at room temperature in transmission mode using a diffractometer equipped with a blue imaging plate detector at the SPring-8 BL19B2 beamline. The crystals were placed in $0.3 \mathrm{~mm}$ glass capillary tubes. The samples were rotated during the measurements. The diffraction patterns were collected using a large Debye-Scherrer camera. The powder simulation patterns were generated from the single-crystal X-ray structures using Mercury 3.0.

Preparation of $\left[\mathrm{Au}_{2}(\mathrm{dppm})_{3}\right] \mathrm{Cl}_{2} \cdot 8.5 \mathrm{H}_{2} \mathrm{O}\left([1] \mathrm{Cl}_{2} \cdot 8.5 \mathrm{H}_{2} \mathrm{O}\right)$. To a white suspension containing $50 \mathrm{mg}(0.059 \mathrm{mmol})$ of $\left[\mathrm{Au}_{2} \mathrm{Cl}_{2}(\mathrm{dppm})\right]$ in $\mathrm{MeOH}(5 \mathrm{~mL})$ was added a solid sample of dppm $(46 \mathrm{mg}, 0.12 \mathrm{mmol})$. The mixture was sonicated for $1 \mathrm{~min}$, producing a clear yellow solution. $\mathrm{H}_{2} \mathrm{O}(2 \mathrm{~mL})$ was added to the yellow solution, which was allowed to stand at room temperature for 5 days. The resulting pale yellow block crystals suitable for X-ray analysis were collected via filtration. Yield: $88 \mathrm{mg}(85 \%)$. Anal. Found: C, 50.88; H, 4.65\%. Calcd for $\left[\mathrm{Au}_{2}(\mathrm{dppm})_{3}\right]$ $\mathrm{Cl}_{2} \cdot 8.5 \mathrm{H}_{2} \mathrm{O}=\mathrm{C}_{75} \mathrm{H}_{83} \mathrm{O}_{8.5} \mathrm{P}_{6} \mathrm{Au}_{2} \mathrm{Cl}_{2}: \mathrm{C}, 50.86 ; \mathrm{H}, 4.72 \%$. IR spectrum $\left(\mathrm{cm}^{-1}, \mathrm{KBr}\right.$ disk): $1436\left(\nu_{\mathrm{Ph}}\right), 1097$ and 784, $694\left(\nu_{\mathrm{P}-\mathrm{Ph}}\right) .{ }^{1} \mathrm{H}$ NMR spectrum (ppm from TMS, CD $\left.\mathrm{OD}\right): 7.84-7.79(\mathrm{~m}, 8 \mathrm{H}), 7.59-7.50(\mathrm{~m}, 12 \mathrm{H}), 3.98(\mathrm{dd}, 2 \mathrm{H}$, $\left.J_{1}=10.1 \mathrm{~Hz}, J_{2}=4.6 \mathrm{~Hz}\right), 2.92-2.85(\mathrm{~m}, 6 \mathrm{H}), 2.66\left(\mathrm{dd}, 2 \mathrm{H}, J_{1}=16.7 \mathrm{~Hz}, J_{2}=4.8 \mathrm{~Hz}\right) .{ }^{31} \mathrm{P}$ NMR spectrum $(\mathrm{ppm}$ from $\left.80 \% \mathrm{H}_{3} \mathrm{PO}_{4}, \mathrm{CD}_{3} \mathrm{OD}\right): 37.085$.

Preparation of $\left[\mathrm{Au}_{2}(\mathrm{dppm})_{3}\right](\mathrm{OTf})_{2} \cdot \mathrm{H}_{2} \mathrm{O}\left([1](\mathrm{OTf})_{2} \cdot \mathrm{H}_{2} \mathrm{O}\right)$. To a white suspension containing $50 \mathrm{mg}$ $(0.059 \mathrm{mmol})$ of $\left[\mathrm{Au}_{2} \mathrm{Cl}_{2}(\mathrm{dppm})\right]$ in $\mathrm{MeOH}(5 \mathrm{~mL})$ was added a solid sample of dppm $(46 \mathrm{mg}, 0.12 \mathrm{mmol})$. The mixture was sonicated for $1 \mathrm{~min}$, producing a clear yellow solution. A solution containing $25 \mathrm{mg}(0.145 \mathrm{mmol})$ of $\mathrm{NaOTf}$ in a mixture of $\mathrm{H}_{2} \mathrm{O}(1 \mathrm{~mL})$ and $\mathrm{MeOH}(7 \mathrm{~mL})$ was added to the yellow solution, followed by allowing it to stand at room temperature for 2 days. The resulting pale-yellow plate crystals suitable for X-ray analysis were collected via filtration. Yield: $97 \mathrm{mg}(88 \%)$. Anal. Found: C, 49.86; H, 3.69\%. Calcd for $\left[\mathrm{Au}_{2}(\mathrm{dppm})_{3}\right]$ $(\mathrm{OTf})_{2} \cdot \mathrm{H}_{2} \mathrm{O}=\mathrm{C}_{77} \mathrm{H}_{68} \mathrm{O}_{7} \mathrm{~S}_{2} \mathrm{P}_{6} \mathrm{Au}_{2} \mathrm{~F}_{6}: \mathrm{C}, 49.64 ; \mathrm{H}, 3.68 \%$. IR spectrum $\left(\mathrm{cm}^{-1}, \mathrm{KBr}\right.$ disk): $1436\left(\nu_{\mathrm{Ph}}\right), 1097$ and 775 , $693\left(v_{\mathrm{P}-\mathrm{Ph}}\right)$.

Thermal conversion of $[1] \mathrm{Cl}_{2} \cdot 8.5 \mathrm{H}_{2} \mathrm{O}$. A pale yellow crystalline powder of $[1] \mathrm{Cl}_{2} \cdot 8.5 \mathrm{H}_{2} \mathrm{O}$ was heated at $373 \mathrm{~K}$ for $30 \mathrm{~min}$ under vacuum to produce a dehydrated sample of [1] $\mathrm{Cl}_{2}$. During heating, the color of the powder changed from pale-yellow to yellow. The dehydrated sample of $[1] \mathrm{Cl}_{2}$ was further heated at $399 \mathrm{~K}$ for $30 \mathrm{~min}$. During the second heating, the color of the powder changed from yellow to white. The samples thus obtained were used for the emission and powder X-ray diffraction measurements at ambient temperature.

Luminescence measurements. The luminescence spectra were recorded by a JASCO FP- 8500 spectrometer at room temperature in the solid state or in solution, using a Xe lamp as the light source. The internal emission quantum yields $(\Phi)$ were obtained via the absolute measuring method using an integrating sphere unit (JASCO ILFC-847), the internal surface of which was coated with highly reflective Spectralon. The ESC-842 Calibrated light source (WI) and the ESC-843 Calibrated light source (D2) were used to calibrate the emission intensities to measure the absolute quantum yields. The accuracy of this instrument was confirmed using a Rhodamine B ethylene glycol solution. The measurement was performed according to the following protocol. First, nothing was set on the sample cell holder in the integrating sphere, and then, the spectrum of the incident light was measured. The observed peak area was defined as the area from incident light, $\mathrm{A}_{0}$ (equivalent number of photons in the incident light). Second, the sample on the sample holder was set in the integrating sphere, and the emission spectra of the sample were measured. The obtained excitation wavelength peak area was defined as the area scattered from the sample, $A_{1}$ (equivalent number of photons that were not absorbed), and peak area in the emission wavelength range was defined as the area emitted from the sample, $A_{2}$. Finally, the internal emission quantum 
yields $(\Phi)$ were calculated using the following equation: $\Phi=\mathrm{A}_{2} /\left(\mathrm{A}_{0}-\mathrm{A}_{1}\right)$. We have measured $\Phi$ values for more than 10 samples of $[1] \mathrm{Cl}_{2} \cdot 8.5 \mathrm{H}_{2} \mathrm{O}$ or $[1](\mathrm{OTf})_{2} \cdot \mathrm{H}_{2} \mathrm{O}$. As a result, the observed $\Phi$ values varied in the range of $99-104 \%$ for $[1] \mathrm{Cl}_{2} \cdot 8.5 \mathrm{H}_{2} \mathrm{O}$ and $99-101 \%$ for $[1](\mathrm{OTf})_{2} \cdot \mathrm{H}_{2} \mathrm{O}$. The fluctuations in the $\Phi$ values (maximum of $5 \%$ ) should be regarded as the random error of measurements. In addition, we have measured the absolute quantum yields of Quinine sulfate in a degassed $0.5 \mathrm{M} \mathrm{H}_{2} \mathrm{SO}_{4}$ using the same instrument and the same sample cell in order to evaluate the accuracy of the absolute quantum yields observed by the instrument. The observed quantum yield values of $55-57 \%$ were in good agreement with the reported value of $55 \%{ }^{24}$. Considering aforementioned results, we determined that the observed $\Phi$ values contain $5 \%$ error.

Emission lifetime measurements were recorded using a Hamamatsu Photonics, C4334 system equipped with a streak camera as a photo detector and a nitrogen laser for the $337 \mathrm{~nm}$ excitation.

The data of the emission data are summarized in Supplementary Table 1.

X-ray crystal structure determination. The single crystal X-ray diffraction measurements were performed using a Rigaku FR-E Superbright rotating-anode X-ray source with Mo-target $(\lambda=0.71075 \AA$ ), equipped with a Rigaku RAXIS VII imaging plate as a detector, at $200 \mathrm{~K}$. The intensity data were collected via the $\omega$-scan technique and empirically corrected for absorption. The structures of the complexes were solved by direct methods using SHELXS2014 ${ }^{25}$. The structure refinements were carried out using full matrix least-squares (SHELXL2014) ${ }^{25}$. The data are summarized in Supplementary Table 2.

For $[1] \mathrm{Cl}_{2} \cdot 8.5 \mathrm{H}_{2} \mathrm{O}$, one third of the $\left[\mathrm{Au}_{2}(\mathrm{dppm})_{3}\right]^{2+}$ cation, two thirds of the $\mathrm{Cl}^{-}$anion, and two and five sixths of the $\mathrm{H}_{2} \mathrm{O}$ molecules were crystallographically independent. All dppm ligands in the crystal were disordered at two positions, with an occupancy factor of 0.5 . All of the benzene rings of dppm ligands were treated using AFIX 66 constraints and SIMU restraints. Some EADP restraints were applied to model the disordered chlorine and water molecules. All non-hydrogen atoms, except water molecules, were refined anisotropically. Hydrogen atoms were included in the calculated positions, except those of $\mathrm{H}_{2} \mathrm{O}$ molecules. For [1] $(\mathrm{OTf})_{2} \cdot \mathrm{H}_{2} \mathrm{O}$, two $\left[\mathrm{Au}_{2}(\mathrm{dppm})_{3}\right]^{2+}$ cations, four $\mathrm{OTf}^{-}$anions, and two water molecules were crystallographically independent. All of the benzene rings of dppm ligands were treated using AFIX 66 constraints. All non-hydrogen atoms, except one OTf ${ }^{-}$anion, one benzene ring, and one water molecule, which were disordered into two parts with occupancy factors of 0.5 , were refined anisotropically. Hydrogen atoms were included in the calculated positions. Three of the four OTf ${ }^{-}$anions were modeled to adopt ideal conformations using FRAG commands. These anions were treated using EADP or DELU restraints.

$\boldsymbol{A} \boldsymbol{b}$ Initio crystal structure determination of [2] $\mathrm{Cl}_{2} . \quad \mathrm{A}$ high-quality PXRD pattern of [2] $\mathrm{Cl}_{2}$ was recorded at $298 \mathrm{~K}$ in transmission mode [ $0.3 \mathrm{~mm}$ capillary; synchrotron radiation $\lambda=1.3 \AA$; $2 \theta$ range, 0.00 to $78.09^{\circ}$; step size, $0.01^{\circ}$; data collection time, $25 \mathrm{~min}$ ] using a diffractometer equipped with a blue imaging plate detector at the BL19B2 beam line, SPring- 8 .

The PXRD pattern of [2] $\mathrm{Cl}_{2}$ was indexed using the program $\mathrm{DICVOL}^{26}$ to produce a monoclinic unit cell $\left(a=20.588 \AA, b=18.129 \AA, c=12.988 \AA, \beta=98.892^{\circ}, V=4789.27 \AA^{3}\right)$ with good figure of merit. The space group was assigned based on systematic absences as $P 2_{1} / n$. Unit cell and profile refinement were carried out using the Pawley method and led to a good fit $\left(\chi^{2}=3.87\right)$ for these lattice parameters and the space group. The structure solution was obtained using the simulated annealing method with the program $\mathrm{DASH}^{27}$. Two rigid groups: $\left[\mathrm{Au}_{2}(\mathrm{dppm})_{2}\right]$, in which $\mathrm{P}-\mathrm{C}_{\text {phenyl }}$ were allowed to rotate, and two $\mathrm{Cl}^{-}$molecules, in asymmetric units and $Z=4$ for space group $P 2_{1} / n$, were introduced using a constrained $Z$-matrix description. During annealing, 26 runs of $1 \times 10^{7}$ Monte Carlo moves were performed. The best structure obtained (Profile $\chi^{2}=24.45$ ) was taken as the starting structural model for Rietveld refinement. The Rietveld refinement ${ }^{28}$ of [2] $\mathrm{Cl}_{2}$ was performed using the programs RIETAN-FP ${ }^{29}$ and VESTA ${ }^{30}$, introducing disorder for each $\mathrm{Cl}^{-}$anion. Restraints but no constraints for all bond lengths were employed to maintain the molecular geometry. Atomic displacement parameters were refined isotopically. Absorption collection was applied using the RIETAN-FP Program. Final Rietveld refinement result: $a=20.5723(6) \AA, b=18.1157(5) \AA, c=12.975(3) \AA, \beta=98.900(2)^{\circ}, V=4777.5(2) \AA^{3}, R_{\mathrm{wp}}=8.860 \%$ $\left(R_{\mathrm{e}}=10.850 \%\right), R_{\mathrm{p}}=6.403 \%, R_{\mathrm{B}}=6.775 \%, R_{\mathrm{F}}=6.605 \% ; 5,801$ profile points $\left(2 \theta\right.$ range, 2 to $\left.60^{\circ}\right) ; 282$ refined variables. The result is shown in Supplementary Fig. 9.

$A b$ Initio crystal structure determination of $\left[\mathrm{Au}_{2} \mathrm{Cl}_{2}(\mathrm{dppm})_{2}\right]$. A high-quality PXRD pattern of $\left[\mathrm{Au}_{2} \mathrm{Cl}_{2}(\mathrm{dppm})_{2}\right]$, which was prepared from $\left[\mathrm{Au}_{2}(\mathrm{dppm})_{2} \mathrm{Cl}_{2}\right] \cdot($ acetone $)$ after being heated at $399 \mathrm{~K}$, was recorded at $298 \mathrm{~K}$ in transmission mode [ $0.3 \mathrm{~mm}$ capillary; synchrotron radiation $\lambda=1.3 \AA$; $2 \theta$ range, 0.00 to $78.09^{\circ}$; step size, $0.01^{\circ}$; data collection time, $20 \mathrm{~min}$ ] using a diffractometer equipped with a blue imaging plate detector at the BL19B2 beam line, SPring- 8 .

The PXRD pattern of $\left[\mathrm{Au}_{2} \mathrm{Cl}_{2}(\mathrm{dppm})_{2}\right]$ was indexed using the program DICVOL ${ }^{26}$ to produce a triclinic unit cell $\left(a=20.481 \AA, b=14.008 \AA, c=11.237 \AA, \alpha=66.65^{\circ}, \beta=109.83^{\circ}, \gamma=125.98^{\circ}, V=2370.44 \AA^{3}\right)$ with good a figure of merit. The space group was assigned as $P-1$ based on systematic absences. Unit cell and profile refinement were carried out using the Pawley method and led to a good fit $\left(\chi^{2}=3.10\right)$ for these lattice parameters and the space group. The structure solution was carried out using the simulated annealing method with the program DASH. Two rigid groups: $[\mathrm{Au}(\mathrm{dppm})] \mathrm{Cl}$, in which $\mathrm{P}-\mathrm{C}_{\text {phenyl }}$ were allowed to rotate in an asymmetric unit and $Z=2$ for space group $P$-1, were introduced using a constrained $Z$-matrix description. During annealing, 26 runs of $1 \times 10^{7}$ Monte Carlo moves were performed. The best structure obtained (Profile $\chi^{2}=20.92$ ) was taken as the starting structural model for Rietveld refinement. Absorption collection was applied using the RIETAN-FP Program. The Rietveld refinement of $\left[\mathrm{Au}_{2} \mathrm{Cl}_{2}(\mathrm{dppm})_{2}\right]$ was performed using the programs RIETAN-FP and VESTA. Restraints but no constraints for all bond lengths were employed to maintain the molecular geometry. Atomic displacement parameters were refined isotopically. Final Rietveld refinement result: $a=20.4758(0) \AA$, $b=14.0049(0) \AA, c=11.2323(0) \AA ̊ \Omega=66.63(0)^{\circ}, \beta=109.68(0)^{\circ}, \gamma=125.96(0)^{\circ}, V=2368.42(0) \AA^{3}, R_{\mathrm{wp}}=5.150 \%$ 
$\left(R_{\mathrm{e}}=10.504 \%\right), R_{\mathrm{p}}=3.908 \%, R_{\mathrm{B}}=1.505 \%, R_{\mathrm{F}}=0.794 \% ; 5,701$ profile points ( $2 \theta$ range, 3 to $\left.60^{\circ}\right) ; 242$ refined variables. The result is shown in Supplementary Fig. 10.

DFT calculations. DFT calculations for the $[1] \mathrm{Cl}_{2} \cdot \mathrm{H}_{2} \mathrm{O}$ system were performed using the Gaussian 09 program $^{31}$ with the PBE0 functional. The def2-tzvppd basis set was applied for Au and P atoms in $[1]^{2+} .6-311 G(d)$ basis sets were applied for bridging $\mathrm{C}$ atoms between two $\mathrm{P}$ atoms in $[1]^{2+}$, and $6-31 \mathrm{G}$ and STO-3G basis sets were applied for $\mathrm{C}$ and $\mathrm{H}$ atoms in phenyl rings in $[1]^{2+}$, respectively. Additionally, $6-311+\mathrm{G}^{\star}$ basis sets for $\mathrm{Cl}^{-}$ and $\mathrm{H}_{2} \mathrm{O}$ molecules were used. The single-point and time-dependent DFT calculations were carried out for [1] $\mathrm{Cl}_{2} \cdot \mathrm{H}_{2} \mathrm{O}$. The initial structural parameters were taken from the single-crystal X-ray structure of $[1] \mathrm{Cl}_{2} \cdot 8.5 \mathrm{H}_{2} \mathrm{O}$. The contour plots of HOMO-12, HOMO-11 and LUMO are shown in Supplementary Fig. 3. The calculated absorption spectrum of $[1] \mathrm{Cl}_{2} \cdot \mathrm{H}_{2} \mathrm{O}$ is illustrated in Supplementary Fig. 4 . The major components in the calculated absorption spectrum were summarized in Supplementary Table 3. The optimized molecular structures in the singlet ground state and triplet excitation state are demonstrated in Supplementary Fig. 15.

\section{References}

1. Keefe, M. H., Benkstein, K. D. \& Hupp, J. T. Luminescent sensor molecules based on coordinated metals: a review of recent developments. Coord. Chem. Rev. 205, 201-228 (2000).

2. Zhang, X. et al. Recent advances in mechanochromic luminescent metal complexes. J. Mater. Chem. C 1, 3376-3390 (2013).

3. Wenger, O. S. Vapochromism in Organometallic and Coordination Complexes: Chemical Sensors for Volatile Organic Compounds Chem. Rev. 113, 3686-3733 (2013).

4. Katz, M. J., Ramnial, T., Yu, H. \& Leznoff, D. B. Polymorphism of $\mathrm{Zn}\left[\mathrm{Au}(\mathrm{CN})_{2}\right]_{2}$ and Its Luminescent Sensory Response to $\mathrm{NH}{ }_{3}$ Vapor. J. Am. Chem. Soc. 130, 10662-10673 (2008).

5. Jobbágy, C. et al. stimuli-responsive double-stranded digold(I) helicate. CrystEngComm 16, 3192-3202 (2014).

6. Saitoh, M., Balch, A. L., Yuasa, J. \& Kawai, T. Effects of Counter Anions on Intense Photoluminescence of 1-D Chain Gold(I) Complexes. Inorg. Chem. 49, 7129-7134 (2010).

7. Hashimoto, Y. et al. Synthesis, Structures, and Luminescence Properties of Interconvertible $\mathrm{Au}_{2}^{\mathrm{I}} \mathrm{Zn}^{\mathrm{II}}$ and $\mathrm{Au}_{3}^{\mathrm{I}} \mathrm{Zn}^{\mathrm{II}} \mathrm{Complexes}$ with Mixed Bis(diphenylphosphino)methane and d-Penicillaminate. Inorg. Chem. 52, 14368-14375 (2013).

8. Liang, J. et al. Aggregation-induced emission (AIE) behavior and thermochromic luminescence properties of a new gold(I) complex. Chem. Commun. 49, 3567-3569 (2013).

9. Ito, H. et al. Mechanical stimulation and solid seeding trigger single-crystal-to-single-crystal molecular domino transformations. Nat. Commun. 4, 2009-2014 (2013).

10. Pyykkö, P. Strong Closed-Shell Interactions in Inorganic Chemistry. Chem. Rev. 97, 597-636 (1997).

11. Schmidbaur, H. \& Schier, A. A briefing on aurophilicity. Chem. Soc. Rev. 37, 1931-1951 (2008).

12. King, C., Wang, J., Khan, M. N. I. \& Fackler, J. P. Jr. Luminescence and Metal-Metal Interactions in Binuclear Gold(I) Compounds. Inorg. Chem. 28, 2145-2149 (1989).

13. Tanase, T. et al. Strongly Luminous Tetranuclear Gold(I) Complexes Supported by Tetraphosphine Ligands, meso- or racBis[(diphenylphosphinomethyl)phenylphosphino]methane. Chem. Eur. J. 20, 1577-1596 (2014).

14. Li, D., Che, C., Kwong, H. \& Yam, V. W. W. Photoinduced C-C Bond Formation from Alkyl Halides catalysed by Luminescent Dinuclear Gold(I) and Copper(I) Complexes. J. Chem. Soc., Dalton trans. 3325-3329 (1992).

15. Shieh, S. Li, D., Peng, S. \& Che, C. Synthesis, Photophysical Properties and Crystal Structure of a Luminescent Binuclear Threecoordinated Gold(I) Complex without Metal-Metal Interaction. J. Chem. Soc., Dalton trans. 195-196 (1993).

16. Yam, V. W. \& Lee, W. Synthesis, Spectroscopy and Excited-state Redox Properties of Novel Luminescent Trinuclear Three-coordinate Gold(I) Phosphine Complexes. J. Chem. Soc., Dalton trans. 2097-2100 (1993).

17. Wei, Z. et al. Rigidifying Fluorescent Linkers by Metal-Organic Framework Formation for Fluorescence Blue Shift and Quantum Yield Enhancement. J. Am. Chem. Soc. 136, 8269-8276 (2014).

18. Al-Baker, S., Hill, W. E. \& McAuliffe, C. A. Novel Ring Compounds of Bidentate Phosphines with Gold(I). Two-, Three-, and Fourco-ordination. J. Chem. Soc. Dalton trans. 2655-2659 (1985).

19. Mirabelli, C. K. et al. Antitumor Activity of Bis(diphenylphosphino)alkanes, Their Gold(I) Coordination Complexes, and Related Compounds. J. Med. Chem. 30, 2181-2190 (1987).

20. Nakamoto, K. Infrared and Raman Spectra of Inorganic and Coordination Compounds, part A, $5^{\text {th }}$ ed., Sec. II, 153-320 (Wiley, 2008).

21. Hong, M. et al. Syntheses, structures and spectroscopic properties of $\left[\mathrm{Ag}(\mathrm{dppm})\left(\mathrm{O}_{2} \mathrm{CCH}_{2} \mathrm{Ph}\right)\right]_{2}$ and $\left[\mathrm{Ag}_{2}(\mathrm{dppm})_{3}\right]\left(\mathrm{NO}_{3}\right)_{2} \cdot 3 \mathrm{H}_{2} \mathrm{O}$. Polrhedron 16, 11, 1957-1962 (1977).

22. Gimeno, M. C. \& Laguna A. Three- and Four-Coordinate Gold(I) Complexes. Chem. Rev. 97, 3, 511-522 (1997).

23. Schmidbaur, H. et al. \& Gold-Komplexe von Diphosphinomethanen, I. I. Synthese und Kristallstruktur achtgliedriger Ringverbindungen von Gold(I) mit Au-Au-Wechselwirkung. Chem. Ber. 110, 2751-2757 (1977).

24. Birks, J. B. Fluorescence quantum yield measurement. J. Res. Natl. Bur. Stand. A 80, 389-399 (1976).

25. Sheldrick, G. M. A short history of SHELX. Acta Cryst. A 64, 112-122 (2008).

26. Boultif, A. \& Louër, D. Indexing of powder diffraction patterns for low-symmetry lattices by the successive dichotomy method. J. Appl. Crystallogr. 24, 987-993 (1991).

27. David, W. I. F. et al. DASH: a program for crystal structure determination from powder diffraction data. J. Appl. Crystallogr. 39, 910-915 (2006)

28. Rietveld, H. M. A profile refinement method for nuclear and magnetic structures. J. Appl. Crystallogr. 2, 65-71 (1969).

29. Izumi, F. \& Momma, K. Three-dimensional visualization in powder diffraction. Solid State Phenom. 130, 15-20 (2007).

30. Momma, K. \& Izumi, F. VESTA: a three-dimensional visualization system for electronic and structural analysis. J. Appl. Crystallogr. 41, 653-658 (2008).

31. Frisch, M. J. et al. Gaussian 09, Revision C.01 (2009), Gaussian, Inc., Wallingford CT. URL http://www.gaussian.com/.

\section{Acknowledgements}

This work was supported by CREST, JST. The synchrotron radiation experiments were performed at the BL19B2 of SPring- 8 with the approval of the Japan Synchrotron Radiation Research Institute (JASRI) (Proposal No. 2014B1022). One of the authors (KI) acknowledges Programs for Leading Graduate Schools: 'Interactive Material Science Cadet Program'. We thank Prof. Masako Kato (Hokkaido University, Japan) for the emission lifetime measurements. Dr. Yuji Hashimoto (Osaka University, Japan) is also acknowledged for his experimental support. 


\section{Author Contributions}

K.I. conducted the synthesis and spectroscopic measurements of compounds; N.Y. performed single-crystal X-ray diffraction analyses; H.O. and M.K. performed powder X-ray diffraction analyses; M.O. performed DFT calculations; K.I., N.Y. and T.K. wrote the manuscript; T.K. conceived and designed the project. All authors discussed the results and commented on the manuscript.

\section{Additional Information}

Accession codes: The X-ray crystallographic coordinates for the structure reported in this Article have been deposited at the Cambridge Crystallographic Data Centre (CCDC) under deposition number CCDC 14377801437781 (powder data), 1437852-1437853 (single-crystal data). These data can be obtained free of charge from The Cambridge Crystallographic Data Centre via www.ccdc.cam.ac.uk/data_request/cif.

Supplementary information accompanies this paper at http://www.nature.com/srep

Competing financial interests: The authors declare no competing financial interests.

How to cite this article: Igawa, K. et al. Crystalline-Amorphous-Crystalline Transformation in a Highly Brilliant Luminescent System with Trigonal-Planar Gold(I) Centers. Sci. Rep. 6, 26002; doi: 10.1038/srep26002 (2016).

(c) (i) This work is licensed under a Creative Commons Attribution 4.0 International License. The images or other third party material in this article are included in the article's Creative Commons license, unless indicated otherwise in the credit line; if the material is not included under the Creative Commons license, users will need to obtain permission from the license holder to reproduce the material. To view a copy of this license, visit http://creativecommons.org/licenses/by/4.0/ 